\title{
RESEARCH
}

SCIEnTIA Marina 70S3

R. Sardá, G. San Martín, E. López, D. Martin

and D. George (eds.)

December 2006, 145-150, Barcelona (Spain)

ISSN: 0214-8358

\section{A new species of Rullierinereis and new records of Nereididae from sublittoral sandy bottoms off Lanzarote (Canary Islands)}

\author{
JORGE NÚÑEZ and MARÍA DEL CARMEN BRITO
}

Laboratorio de Bentos, Departamento de Biología Animal (Zoología), Facultad de Biología, Universidad de La Laguna, 38206 La Laguna, Tenerife, Canary Islands, Spain. E-mail: janunez@ull.es

\begin{abstract}
SUMMARY: Rullierinereis ancornunezi n. sp., collected from sandy and maërl bottoms from 19-55 m depth around Lanzarote island, is described. The new taxon is characterized by having a reduced or absent upper notopodial ligule in biramous parapodia of chaetigers 3-9 and in the middle region from chaetiger 26 onwards, and also by the shape of the homogomph notopodial falciger blade, which is short and serrated. A comparison with morphologically similar species is made. Other nereidid species collected were: Nereis lamellosa Ehlers, 1864, Nereis rava Ehlers, 1864, Neanthes caudata (Delle Chiaje, 1827) and Neanthes rubicunda (Ehlers, 1864). A map of the distribution of these species is presented.

Keywords: Polychaeta, Nereididae, Rullierinereis, new species, Lanzarote, Canary Islands.

RESUMEN: UNA NUEVA ESPECIE DE RULLIERINEREIS Y NUEVOS REGISTROS DE NEREIDIDAE PROCEDENTES DE FONDOS SUBLITORALES ARENOSOS EN LOS ALREDEDORES DE LANZAROTE (ISLAS CANARIAS). - Rullierinereis ancornunezi n. sp., colectado en fondos arenosos y de maërl a 19-55 m de profundidad en la isla de Lanzarote, es descrito. El nuevo táxon se caracteriza por tener reducida la lígula superior notopodial de los parápodos birrámeos desde los setígeros 3-9 y en la región media, y por la forma de la seda falcígera homogonfa notopodial, ya que la hoja es corta y espinulada. Se realiza una comparación con especies morfológicamente similares. Otras especies de nereídidos encontradas fueron: Nereis lamellosa Ehlers, 1864, Nereis rava Ehlers, 1864, Neanthes caudata (Delle Chiaje, 1827) and Neanthes rubicunda (Ehlers, 1864). Se presenta un mapa de la distribución de estas especies en la isla de Lanzarote.
\end{abstract}

Palabras clave: Polychaeta, Nereididae, Rullierinereis, nueva especie, Lanzarote, Islas Canarias.

\section{INTRODUCTION}

Nereididae is one of the macrofaunal polychaete groups well represented in intertidal, subtidal and deep water sediments (Fauchald, 1977). In the Canaries, studies on this family are all from intertidal and shallow waters (Núñez, 1993; 1995; Núñez et al., 1981; 1984; 2000; Pascual et al., 2003), and currently 18 species are known from this area (Núñez, 2003).
In this investigation the nereidid species collected during the years 2000 and 2001 in soft bottoms from Lanzarote, the northernmost island of the Canary Archipelago, were studied (Fig. 3). The survey was undertaken off Lanzarote, La Graciosa and Alegranza by the "Centro de Investigaciones Submarinas S.A." (C.I.S.) project research "Estudio ecocartográfico del litoral de Lanzarote, $\mathrm{La}$ Graciosa y Alegranza (Gran Canaria)" n ${ }^{\circ} 28$ 1326/99, for the Spanish Ministry of Environment. 
146 • J. NÚÑEZ and M.C. BRITO

TABLE 1. - Station data

\begin{tabular}{|c|c|c|c|c|c|c|c|c|c|}
\hline \multirow[t]{2}{*}{ Station } & \multicolumn{2}{|c|}{ Coordinates } & \multirow[t]{2}{*}{ Depth m } & \multirow[t]{2}{*}{ Habitat } & \multirow[t]{2}{*}{ Station } & \multicolumn{2}{|c|}{ Coordinates } & \multirow{2}{*}{ Depth $\mathrm{m}$} & \multirow[t]{2}{*}{ Habitat } \\
\hline & UTM X & UTM Y & & & & UTM X & UTM Y & & \\
\hline D-6 & 646009 & 3233999 & 15 & medium sand & D-166 & 648399 & 3235540 & 20 & medium sand \\
\hline D-9 & 645032 & 3232445 & 10 & medium sand & D-167 & 648254 & 3235253 & 18 & fine sand \\
\hline D-10 & 644498 & 3232501 & 12 & medium sand & D-171 & 644444 & 3229502 & 15 & medium sand \\
\hline D-16 & 643001 & 3231999 & 30 & fine medium sand & D-181 & 643997 & 3231497 & 20 & fine sand \\
\hline D-33 & 643505 & 3228495 & 20 & fine medium sand & D-182 & 644494 & 3231559 & 13 & fine sand \\
\hline D-35 & 644443 & 3228715 & 5 & fine sand & D-183 & 644267 & 3230961 & 17 & coarse sand \\
\hline D-37 & 642997 & 3237995 & 25 & fine medium sand & D-190 & 640993 & 3226944 & 29 & coarse sand \\
\hline D-38 & 642495 & 3238026 & 27 & fine medium sand & D-191 & 641008 & 3228967 & 36 & coarse sand \\
\hline D-41 & 640922 & 3227821 & 32 & rocky & D-193 & 648498 & 3241002 & 50 & medium sand \\
\hline D-42 & 641495 & 3227497 & 33 & coarse sand & D-195 & 647497 & 3240749 & 42 & fine sand \\
\hline D-43 & 641997 & 3227498 & 30 & fine medium sand & D-200 & 645496 & 3241501 & 26 & medium sand \\
\hline D-45 & 642998 & 3227497 & 22 & fine medium sand & D-205 & 646995 & 3241511 & 43 & fine sand \\
\hline D-47 & 642503 & 3227000 & 24 & fine medium sand & D-206 & 647534 & 3241811 & 49 & medium sand \\
\hline D-48 & 642003 & 3226991 & 29 & fine medium sand & D-207 & 645251 & 3241504 & 24 & medium sand with maërl \\
\hline D-49 & 641997 & 3226504 & 28 & medium sand & D-209 & 647498 & 3241999 & 45 & medium sand with maërl \\
\hline D-51 & 642998 & 3226496 & 17 & fine medium sand & D-212 & 648503 & 3243000 & 54 & medium sand \\
\hline D-55 & 643263 & 3225000 & 8 & fine medium sand & D-219 & 646497 & 3242497 & 43 & medium sand \\
\hline D-56 & 643003 & 3225003 & 12 & fine sand & D-220 & 646001 & 3242501 & 42 & medium sand \\
\hline D-57 & 642502 & 3225000 & 18 & fine sand & D-221 & 644999 & 3242502 & 32 & medium sand \\
\hline D-58 & 642502 & 3225500 & 19 & fine medium sand & D-290 & 654450 & 3231861 & 33 & medium sand with maërl \\
\hline D-59 & 641990 & 3225510 & 24 & medium sand & D-291 & 655001 & 3232004 & 52 & medium sand \\
\hline D-65 & 639599 & 3229992 & 48 & medium sand & D-292 & 655098 & 3231596 & 54 & medium sand \\
\hline D-75 & 643992 & 3239505 & 8 & medium sand & D-294 & 655000 & 3230501 & 47 & medium sand \\
\hline D-82 & 643004 & 3239505 & 35 & medium sand & D-296 & 655500 & 3230000 & 53 & medium sand with maërl \\
\hline D-83 & 642498 & 3238894 & 47 & medium sand & D-297 & 655500 & 3230000 & 52 & medium sand with maërl \\
\hline D-84 & 642998 & 3238999 & 35 & medium sand & D-310 & 653496 & 3225501 & 32 & medium sand with maërl \\
\hline D-85 & 643513 & 3239066 & 16 & medium sand & D-311 & 654003 & 3226500 & 34 & medium sand with maërl \\
\hline D-86 & 643067 & 3237631 & 34 & medium sand & D-314 & 654600 & 3228097 & 34 & coarse sand \\
\hline D-87 & 642501 & 3237499 & 41 & medium sand & D-316 & 655501 & 3228503 & 48 & medium sand with maërl \\
\hline D-88 & 642014 & 3237212 & 56 & fine sand & D-320 & 655502 & 3228996 & 50 & coarse sand with maërl \\
\hline D-89 & 642021 & 3235860 & 45 & medium sand & D-321 & 655000 & 3229601 & 42 & medium sand with maërl \\
\hline D-90 & 642918 & 3235607 & 45 & fine sand & D-366 & 644499 & 3204999 & 44 & fine sand \\
\hline D-92 & 641697 & 3231502 & 38 & medium sand & D-398 & 634982 & 3198284 & 54 & fine sand \\
\hline D-93 & 642193 & 3231557 & 37 & fine medium sand & D-412 & 644020 & 3204502 & 44 & fine sand \\
\hline D-94 & 642503 & 3231497 & 36 & fine medium sand & D-437 & 649996 & 3214243 & 36 & coarse sand \\
\hline D-95 & 642999 & 3231497 & 33 & fine medium sand & D-525 & 620000 & 3191000 & 23 & medium sand \\
\hline D-97 & 642998 & 3231000 & 32 & fine medium sand & D-530 & 694980 & 3190000 & 30 & medium sand \\
\hline D-98 & 642502 & 3231003 & 34 & fine medium sand & D-533 & 619302 & 3188450 & 53 & medium sand \\
\hline D-99 & 641000 & 3223002 & 13 & fine sand & D-536 & 619138 & 3187023 & 54 & medium sand \\
\hline D-101 & 640001 & 3223001 & 15 & fine sand & D-537 & 619040 & 3186521 & 54 & medium sand \\
\hline D- 105 & 638500 & 3224001 & 27 & fine medium sand & D-540 & 619002 & 3186502 & 50 & medium sand \\
\hline D-107 & 638998 & 3223500 & 22 & medium sand & D-542 & 619001 & 3187502 & 40 & medium sand \\
\hline D-109 & 639502 & 3224000 & 23 & fine medium sand & D-543 & 619001 & 3187999 & 38 & medium sand \\
\hline D-117 & 643464 & 3229115 & 24 & fine medium sand & D-547 & 619102 & 3190149 & 24 & medium sand \\
\hline D-119 & 649504 & 3238502 & 49 & medium sand & D-584 & 616999 & 3188502 & 36 & medium sand \\
\hline D-123 & 649999 & 3238002 & 54 & medium sand & D- 625 & 615501 & 3189501 & 35 & medium sand \\
\hline D-124 & 649498 & 3238002 & 49 & medium sand & D-626 & 615500 & 3189001 & 36 & medium sand \\
\hline D-134 & 649501 & 3239001 & 50 & medium sand & D-628 & 615499 & 3188002 & 36 & medium sand \\
\hline D- 137 & 649999 & 3239499 & 55 & medium sand & D-630 & 615000 & 3188000 & 37 & medium sand \\
\hline D-147 & 649502 & 3237499 & 50 & medium sand & D-631 & 614999 & 3187502 & 37 & medium sand \\
\hline D-148 & 649502 & 3238000 & 49 & medium sand & D-632 & 615003 & 3186998 & 38 & medium sand \\
\hline D- 150 & 648500 & 3236996 & 32 & coarse sand & D-633 & 615498 & 3187001 & 39 & medium sand \\
\hline D- 151 & 648996 & 3237001 & 38 & coarse sand & D-634 & 615498 & 3186498 & 39 & medium sand \\
\hline D- 152 & 649498 & 3237000 & 47 & fine sand & D-635 & 617499 & 3185502 & 37 & medium sand \\
\hline D-157 & 647501 & 3236003 & 23 & medium sand & D-660 & 614500 & 3190004 & 37 & medium sand \\
\hline D-158 & 648997 & 3240500 & 52 & fine sand & D-676 & 613500 & 3191498 & 25 & medium sand \\
\hline D- 160 & 647999 & 3240502 & 45 & medium sand & D-704 & 612001 & 3191999 & 31 & medium sand \\
\hline D- 163 & 647500 & 3235496 & 19 & medium sand & & & & & \\
\hline
\end{tabular}

\section{MATERIAL AND METHODS}

A total of 790 samples from about 5-50 m depth were dredged from around the coasts of Lanzarote, La Graciosa and Alegranza. A modified Foster-type dredge of 28 litres capacity was used. The sandy samples were washed and screened through a $1 \mathrm{~mm}$ mesh sieve. The specimens were fixed with $10 \%$ formaldehyde in seawater, and were subsequently transferred to $70 \%$ ethanol. One specimen was examined with scanning electron microscopy (SEM, Jeol JSM6300), after critical point drying and gold sputtering.

The material was deposited in the collections of the Department of Animal Biology of the University 


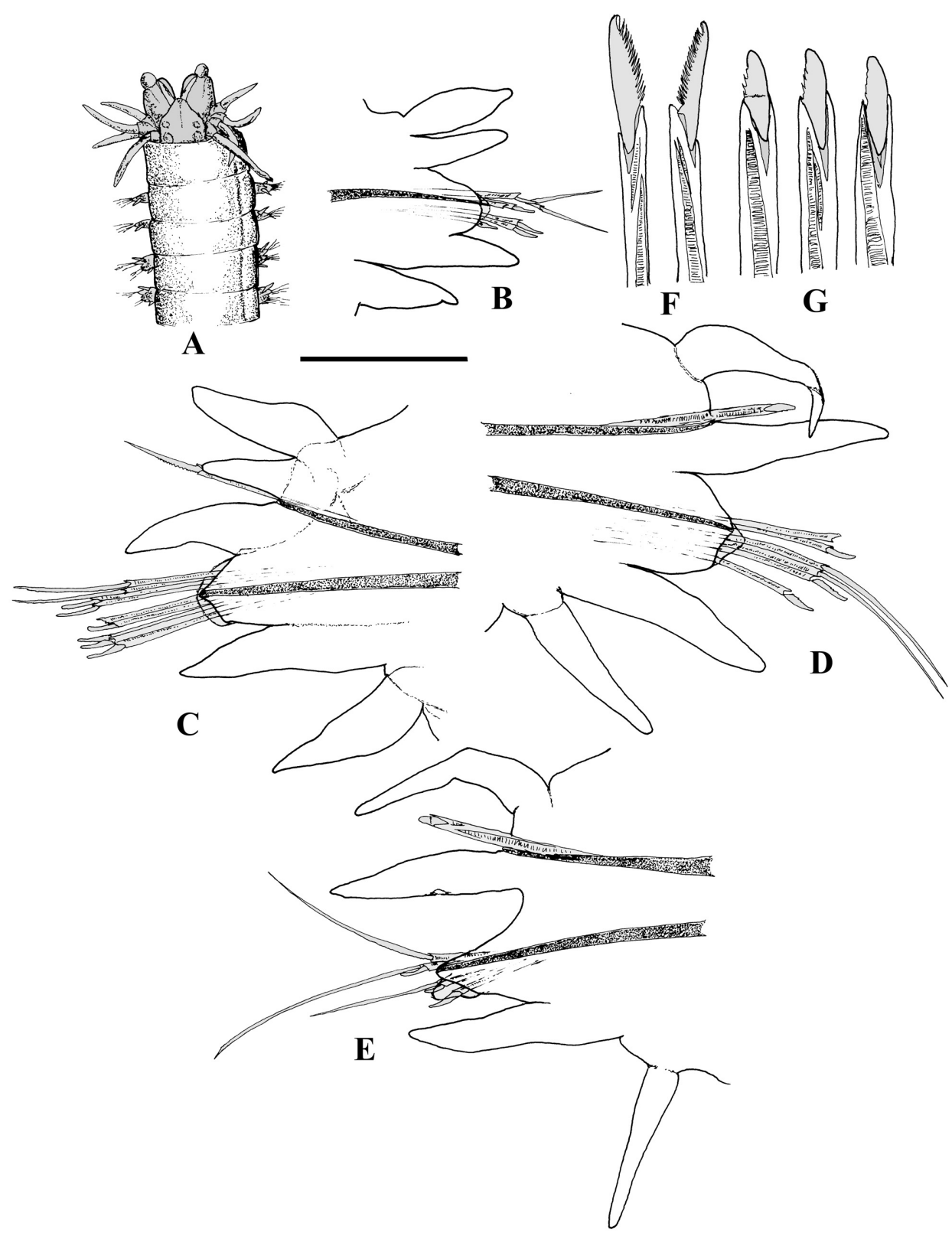

FIG. 1. - A, anterior end dorsal view; B, uniramous parapodium, chaetiger 2, anterior view; C, biramous parapodium, chaetiger 15, posterior view; D, parapodium, chaetiger 30, posterior view; $\mathrm{E}$, parapodium, chaetiger 49, posterior view; $\mathrm{F}$, heterogomph falcigerous neurochaetae; $\mathrm{G}$, Homogomph falcigerous notochaetae.Scale bar for all figures: $\mathrm{A}=1.3 \mathrm{~mm} ; \mathrm{B}-\mathrm{E}=125 \mu \mathrm{m} ; \mathrm{F}, \mathrm{G}=42 \mu \mathrm{m}$.

of La Laguna (DBAULL) and the Museum of Natural Sciences of Tenerife (TFMC).

\section{RESULTS}

A total of 4,155 polychaete specimens belonging to 107 species were identified. Five species and 486 specimens were nereidids. Neanthes rubicunda (Ehlers, 1864) was the most abundant species with 476 specimens. The nereidid specimens were collected from 115 stations (see Table 1).

\section{Rullierinereis ancornunezi $\mathrm{n}$. sp.}

(Figs. 1, 2, 3A)

Type locality. Canary Islands, Lanzarote.

Type material. Holotype: TFMCBMAN/000220, sta. D-167. Paratypes: DBAULL PO-0065, sta. D-65, 1 spec.; DBAULL PO0137, sta. D-137, 1 spec.; DBAULL PO-0294, sta. D-294, 1 spec.; DBAULL PO-0296, sta. D-296, 1 spec.; DBAULL PO-0633, 1 spec.; TFMCBMAN/000221, sta. D-660, 1 spec (see distribution map Fig. 3A).

Additional material. - Canary Islands, Tenerife, Granadilla coast, DBAULL PO-ST77A, $1 \mathrm{spec}$ May 2004; DBAULL PO-ST81B, 1 spec., May 2004; DBAULL PO-ST82B, 1 spec., May 2004. La Gomera, Punta Llana, DBAULL PO-022005, 1 spec., Feb. 2005. 

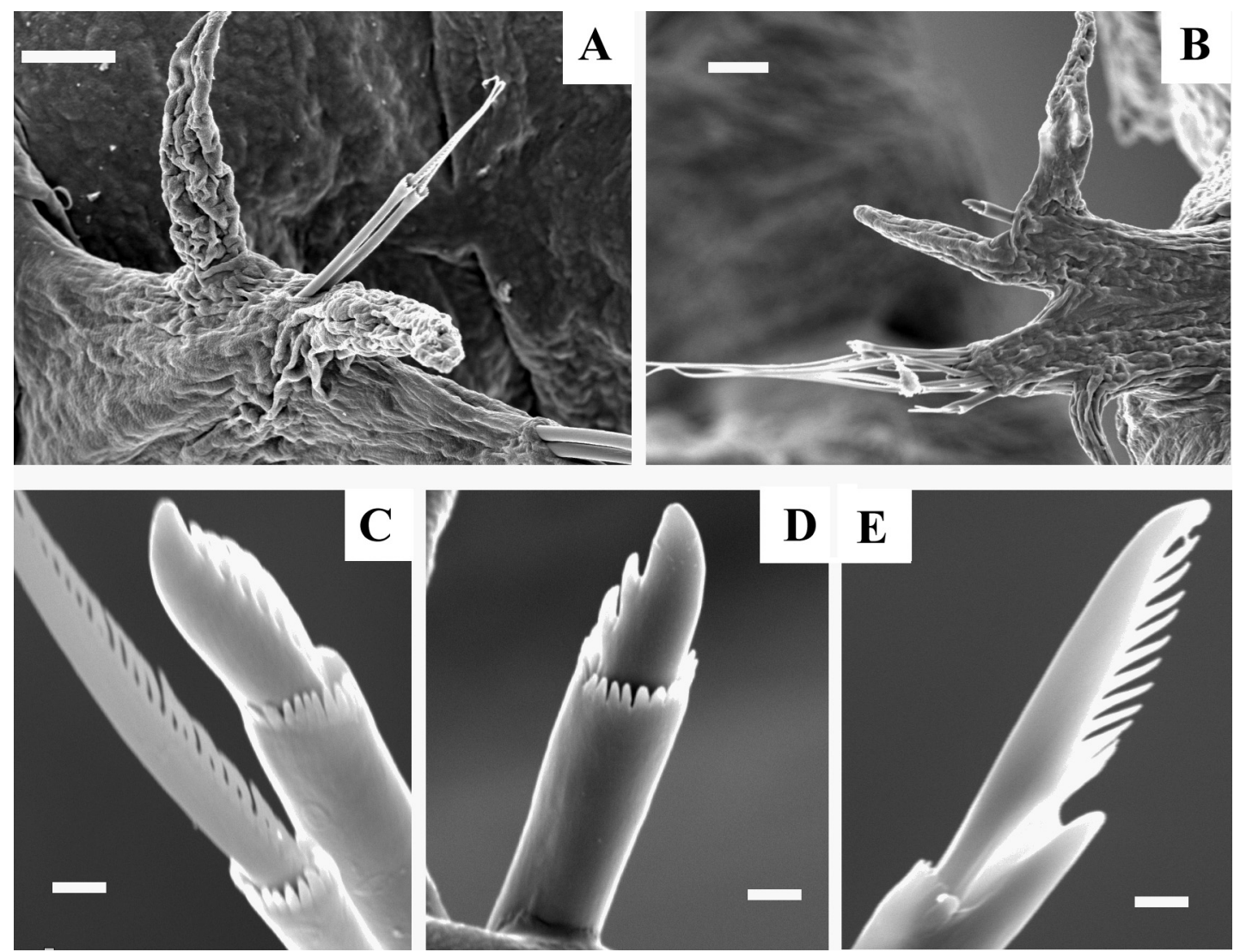

FIG. 2. - A, biramous parapodium, middle region; B, biramous parapodium, posterior region; C, homogonph spiniger and falciger, notopodial chaetae from middle region; $\mathrm{D}$, homogomph falciger, notopodial chaeta from posterior region; E, heterogomph falciger, neuropodial chaeta (SEM photographs).Scale bar: $\mathrm{A}, \mathrm{B}=20 \mu \mathrm{m} ; \mathrm{C}-\mathrm{E}=2 \mu \mathrm{m}$

Description. Holotype incomplete posteriorly with 75 chaetigers, $25 \mathrm{~mm}$ long and $0.85 \mathrm{~mm}$ wide at the second chaetiger (excluding parapodia and chaetae).). Paratypes incomplete posteriorly with 56-81 chaetigers, 9.4-26 mm long and 0.65-0.75 mm wide. Alcohol-preserved specimen lacking pigment patterns. Prostomium subpyriform as long as wide, with two frontal slender antennae, slightly shorter than palps. Palps broad and globose, biarticulate, with globular palpostyles. Eyes in square arrangement, poorly pigmented, posterior pair slightly larger than anterior pair (Fig. 1A). Achaetous segment as wide as first chaetiger, with four pairs of short tentacular cirri, the longest pair extending posteriorly to chaetigers 3-4. Pharynx without paragnaths or papillae. Jaws dark, with six stout large teeth. Parapodia of first two chaetigers uniramous (Fig. 1B), with the dorsal and ventral cirri large and thick; only one notopodial ligule and neuropodium with acicular lobes and one ventral ligule. Parapodia biramous from the third chaetiger, chaetigers 3-5 lack an upper notopodial ligule and in chaetigers 6-9 the ligule is incipient. From approximately chaetigers
10-15 two notopodial ligules present, the upper ligule shorter (Fig. 1C). Dorsal cirri thick, longer than upper ligule and shorter than lower ligule. Neuropodia similar to uniramous parapodia, with two subtriangular acicular lobes shorter than ventral ligule. Ventral cirri thick, slightly shorter than ventral ligule. Parapodia of middle and posterior regions modified, lacking an upper notopodial ligule, lower notopodial ligule well developed, conical-shaped, slightly longer than dorsal cirri. From chaetigers $16-25$ the upper notopodial ligule is reduced or absent (Fig. 2A). Starting from chaetiger 26 the upper notopodial ligule is incipient and on chaetigers 30-45 the ligule disappears (Figs. 1D,E; 2B). Neuropodia with subtriangular acicular lobes, shorter than lower neuropodial ligule. Ventral cirri subulate, shorter than lower ligule. Uniramous parapodia with few chaetae, upper bundle of neuropodia with 0-2 homogomph spinigers and 2-3 heterogomph falcigers; lower bundle with 2-3 heterogomph falcigers. Biramous parapodia also with few notopodial chaetae; chaetigers 3-14 or 16 with only 1-2 homogomph spinigers, from chaetigers 15 or 17 
generally one stout homogomph falciger with short blade distally blunt and internal margin with 3-6 proximal spines (Figs. 1G; 2C,D). Upper bundle of neuropodia with 1-4 homogomph spinigers and 1-2 heterogomph falcigers; lower bundle with 1-3 heterogomph spinigers and 1-4 heterogomph falcigers. Heterogomph falcigers of similar shape along the body, with slender and strongly serrated blades (Fig. 1F; 2E). Pygidium unknown.

Etymology. The species name ancornunezi is dedicated to Ancor Núñez-Brito, the authors'son.

Remarks. The genus Rullierinereis Pettibone, 1971 (Pettibone, 1971) belongs to the subfamily Gymnonereidinae (Fitzhugh, 1987). It is characterised by the pharynx being without paragnaths and papillae (exceptionally with papillae on the oral ring); biramous, notopodia with two ligules, in some species the upper ligule can be reduced or absent (fused with dorsal cirri); anterior parapodia with
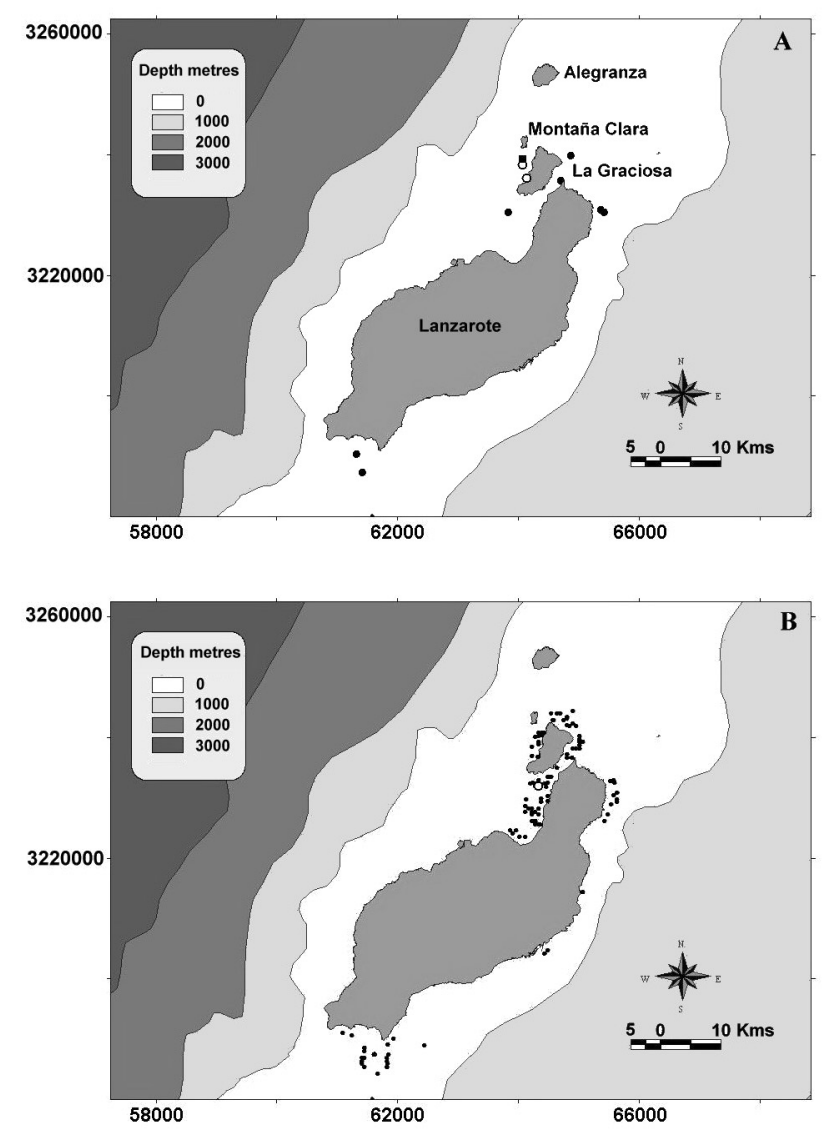

FIG. 3. - A, distribution map of: Rullierinereis ancornunezi n. sp. (black circle); Nereis lamellosa Ehlers, 1864 (black square) and Nereis rava Ehlers, 1864 (open circle); B, distribution map of: Neanthes caudata (Delle Chiaje, 1827) (open circle) and Neanthes rubicunda (Ehlers, 1864) (black circle). notochaetae homogomph spinigers and posteriorly replaced by homogomph falcigers. A total of 14 species are currently known in this genus, of which Rullierinereis tenerifensis Núñez, Brito \& Bacallado, 1984 (Núñez et al., 1984) is a junior synonym of Eunereis longissima (Johnston, 1840).

Three species, $R$. bahamensis (HartmannSchröder, 1958) (Hartmann-Schröder, 1958), $R$. zebra (Rullier, 1963) (Rullier, 1963) and R. auxiliadorae Santos and Lana, 2001 (Santos and Lana, 2001) have reduced upper notopodial ligules on biramous parapodia similar to $R$. ancornunezi $\mathrm{n}$. sp.. However, $R$. bahamensis lacks the upper notopodial ligule from chaetiger $3, R$. zebra lacks the upper ligule in the posterior region and $R$. auxiliadorae lacks the ligule in all chaetigers, while $R$. ancornunezi lacks the upper ligule on chaetigers 3-9 and in the middle-posterior region from chaetiger 26 . The species also can be differentiated by the shape of the homogomph notopodial falciger, which is smooth in $R$. zebra, toothed in $R$. bahamensis and $R$. auxiliadorae, while in $R$. ancornunezi it is serrated with up to 6 spines.

Distribution. Lanzarote, Tenerife, La Gomera (Canary Islands) (Fig. 3A).

Nereis lamellosa Ehlers, 1864

(Fig. 3A)

Nereis lamellosa Ehlers, 1864. Borstenwürmer Syst. Anat. Unters. Dargestellt: 564.

Material examined. Canary Islands, Lanzarote, sta. D-38, 1 spec (see distribution map Fig. 3A).

Distribution. Mediterranean Sea: Sicily and Adriatic. Western Atlantic: east coast of North America. Eastern Atlantic from Cantabrian Sea to Ivory coast. South Africa. Gulf of California.

\section{Nereis rava Ehlers, 1864}

(Fig. 3A)

Nereis rava Ehlers, 1864. Borstenwürmer Syst. Anat. Unters. Dargestellt: 517

Material examined. - Canary Islands, Lanzarote, sta. D-87, $1 \mathrm{spec}$.; sta. D-90, $1 \mathrm{spec}$ (see distribution map Fig. 3A).

Distribution. Atlantic Ocean: North Sea to Cape Verde Islands; in the Macaronesian region has been recorded from the Azores, Madeira and Canary Islands. Mediterranean and Black Sea. 


\section{Neanthes caudata (Delle Chiaje, 1827)}

Spio caudatus Delle Chiaje, 1827. Mem. Stor. Notomia Anim. Senza Vertebr. Regno Napoli, 2(2): 426

Material examined. Canary Islands, Lanzarote, sta. D-97, 1 spec (see distribution map Fig. 3B).

Distribution. Eastern Atlantic: English Channel to South Africa. Western Atlantic: Massachusetts to Gulf of Mexico and Cuba. Mediterranean and Red Sea. Eastern Pacific: Southern California to Mexico. Western Pacific: Japan to Australia and New Zealand.

\section{Neanthes rubicunda (Ehlers, 1864)}

Nereis rubicunda Ehlers, 1864. Borstenwürmer Syst. Anat. Unters. Dargestellt: 529

Material examined. Canary Islands, Lanzarote, sta. D-6, 1 spec.; sta. D-9, 1 spec.; sta. D-10, 3 spec.; sta. D-16, 1 spec.; sta. D-27, 1 spec.; sta. D-28, 1 spec.; sta. D-33, 1 spec.; sta. D-35, 1 spec.; sta. D-37, 1 spec.; sta. D-41, 1 spec.; sta. D-42, 1 spec.; sta. D-43, 1 spec.; sta. D-45, 2 spec.; sta. D-47, 3 spec.; sta. D-48, 9 spec.; sta. D-49, 6 spec; sta D-51, 20 spec.; sta. D-55, 1 spec.; sta. D-56, 8 spec.; sta. D-57, 20 spec.; sta. D-58, 51 spec.; sta. D-59, 44 spec.; sta. D-75, 1 spec.; sta. D-82, 1 spec.; sta. D-83, 1 spec.; sta. D-84, 11 spec.; sta. D-85, 1 spec.; sta. D-86, 1 spec.; sta. D-88, 1 spec.; sta. D-89, 1 spec.; sta. D-90, 3 spec.; sta. D-92, 2 spec.; sta. D-93, 2 spec.; sta. D-94, 2 spec.; sta. D-95, 5 spec.; sta. D-98, 3 spec.; sta. D-99, 3 spec.; sta. D-101, 1 spec.; sta. D-105, 1 spec.; sta. D-107, 4 spec.; sta. D-109, 2 spec.; sta. D-117, 2 spec.; sta. D-119, 1 spec.; sta. D-123, 1 spec.; sta. D-134, 1 spec.; sta. D-147, 1 spec.; sta. D148, 5 spec.; sta. D-150, 9 spec.; sta. D-151, 8 spec.; sta. D-152, 1 spec.; sta. D-157, 1 spec.; sta. D-158, 2 spec.; sta. D-160, 15 spec.; sta. D-163, 3 spec.; sta. D-166, 4 spec.; sta. D-171, 2 spec.; sta. D181, 2 spec.; sta. D-182, 2 spec.; sta. D-183, 2 spec.; sta. D-190, 2 spec.; sta. D-191, 4 spec.; sta. D-193, 2 spec.; sta. D-195, 1 spec.; sta. D-200, 1 spec.; sta. D-205, 1 spec.; sta. D-206, 17 spec.; sta. D207, 15 spec.; sta. D-209, 1 spec.; sta. D-212, 5 spec.; sta. D-219, 1 spec.; sta. D-220, 4 spec.; sta. D-221, 3 spec.; sta. D-290, 16 spec.; sta. D-291, 3 spec.; sta. D-292, 1 spec.; sta. D-296, 2 spec.; sta. D297, 2 spec.; sta. D-310, 1 spec.; sta. D-311, 6 spec.; sta. D-314, 1 spec.; sta. D-316, 1spec.; sta. D-320, 1 spec.; sta. D-321, 1 spec.; sta. D-366, 1 spec.; sta. D-398, 1 spec.; sta. D-412, 1 spec.; sta. D437, 2 spec.; sta. D-525, 4 spec.; sta. D-530, 1 spec.; sta. D-533, 4 spec.; sta. D-536, 5 spec.; sta. D-537, 2 spec.; sta. D-540, 1 spec.; sta. D-542, 1 spec.; sta. D-543, 2 spec.; sta. D-547, 8 spec.; sta. D584, 2 spec., sta. D-625, 2 spec.; sta. D-626, 1 spec.; sta. D-628, 2 spec.; sta. D-630, 1 spec.; sta. D-631, 37 spec.; sta. D-632, 6 spec.; sta. D-634, 8 spec.; sta. D-635, 4 spec.; sta. D-676, 1 spec.; sta. D704, 1 spec (see distribution map Fig. 3B).

Distribution. Atlantic Ocean: Cantabrian Sea, Azores, Madeira, Canary Islands. Western Mediterranean. Indian Ocean: Malay Archipelago, Maldives and Amirantes Islands.

\section{ACKNOWLEDGEMENTS}

We are grateful to Carlos Durán and Roxina Acuña of Centro de Investigaciones Submarinas (C.I.S.) coordinators of the project "Estudio ecocar- tográfico del litoral de Lanzarote, La Graciosa y Alegranza" and to Ministerio de Medio Ambiente for the financial support for this study. Thanks to colleagues in the Benthos Laboratory of the La Laguna University, Miriam Rodríguez, Óscar Monterroso y Rodrigo Riera for their help in this study. The help of David George, Torkild Bakken and the Scientific Committee is also appreciated.

\section{REFERENCES}

Delle Chiaje, S. - 1827. Memoria sulla Storia e Notomia degli Animali Senza Vertebre del Regno di Napoli, vol. 2.

Ehlers, E. - 1864. Die Borstenwümer (Annelida Chaetopoda) nach systematischen und anatomischen Untersuchungen. Wilhelm Engelmann, Leipzig.

Fauchald, K. - 1977. Some Nereid Polychaetes from deep water. In: D.J. Reish and K. Fauchald (eds.), Essays on polychaetous annelids in memory of Dr. Olga Hartman, pp. 157-171. Allan Hancock Fdtn, Univ. Southern California, Los Angeles.

Fitzhugh, K. - 1987. Phylogenetic relationships within the Nereididae (Polychaeta): implications at the subfamily level. Bull Biol. Soc. Washington, 7: 174-183.

Hartmann-Schröder, G. - 1958. Einige Polychaeten aus dem Küstengrundwasser der Bimine-Inseln (Bahamas). Kieler Meeresfor-schungen, 14: 233-240.

Núñez, J - 1993. Redescription of Perinereis taorica Langerhans (Polychaeta: Nereidae) from Tenerife (Canary Islands). Mar. Life, 3: 31-35.

Núñez, J. - 1995. Aportaciones sobre cinco especies de Nereidos (Polychaeta, Nereidae) y clave para la identificación de las especies presentes en Canarias. Vieraea, 24: 71-85.

Núñez, J. - 2003. Annelida. In: L. Moro, J.L. Martín, M.J. Garrido and I. Izquierdo (eds.), Lista de especies marinas de Canarias (algas, hongos, plantas y animales), pp, 51-57. Consejería de Política Territorial y Medio Ambiente del Gobierno de Canarias.

Núñez, J., J.J. Bacallado and M.C. Brito. - 1981. Nereidae (Polychaeta Errantia) de las costas del Archipiélago Canario. Bol. Inst. Esp. Oceanogr., 4: 162-177.

Núñez, J., M.C. Brito, M.C. and J.J. Bacallado. - 1984. Nueva contribución al conocimiento de la familia Nereidae (Annelida, Polychaeta) de las costas del Archipiélago Canario. An. Fac. Cien., 10: 13-24.

Núñez, J.,R. Riera and M.C. Brito. - 2000. Nuevos registros de Nereídidos (Polychaeta: Nereidae) para las Islas de Cabo Verde y Canarias. Avicennia, 12-13: 115-126

Pascual, M., J. Núñez, R. Riera and M.C. Brito. - 2003. Poliquetos endobiontes de esponjas de Madeira y Canarias: Familias Nereidae y Lacydoniidae. Rev. Acad. Canar. Cienc., 14(3-4): 227-233.

Pettibone, M.H. - 1971. Revision of some species referred to Leptonereis, Nicon and Laeonereis (Polychaeta: Nereididae). Smithsonian Contr. Zool., 104: 1-53:

Rullier, F. - 1963. Une petite collection d'Annélides polychètes de l'Ile Maurice. Bull. Soc. Zool. France, 87: 471-481.

Santos, C.S.G. and P. Lana. - 2001. Nereididae (Annelida, Polychaeta) da costa nordeste do Brasil. II. Gêneros Namalycastis, Ceratocephale, Laeonereis e Rullierinereis. Iheringia, Sér. Zool., Porto Alegre, 91: 137-149.

Received September 15, 2004. Accepted July 4, 2005 